\title{
Officer-Facilitated Homicide: Assessing the Deaths of Mentally III Offenders as a Result of Police Practices
}

\author{
Benjamin A Smith
}

\section{Abstract}

The following essay examines three instances of mentally ill victims of homicide who were police suspects at the time of their death, and whose death was caused by the arresting attending officers. A contextual basis is provided in order to assess the conditions that facilitated those situations. This essay then addresses the questions: Are police adequately equipped to effectively manage interactions with sufferers of mental health crises? If not, why not and how might process, protocol and procedure be improved to reduce the number of deaths resulting from those inadequacies? The essay concludes that members of state police services are inadequately trained and that this inadequacy foreseeably led to the homicides. Adaptations to training modules are suggested that reflect necessary changes in order to avoid further deaths and the essay suggests the problem of mentally ill offenders be viewed as a whole-of-community issue requiring whole-of-community responses.

\section{Introduction}

Police work involves frequent interaction with mentally ill persons and a growing body of evidence suggests that these interactions are inadequately managed. The extreme consequence of this is the death of persons with mental illness (PMI); which may be avoided if police respond more effectively. This essay provides a contextual history of developments in mental health treatment and identifies some of the consequences of this. It presents three case studies and highlights common factors between them and analyses developing PMI policy. The essay advances four major arguments: 1) Police need specific, ongoing training to respond to PMI; 2) Force, particularly lethal force, should be employed only when there is a clearly defined threat to life or health, and only 
as a last resort; and, 3) A whole-of-government approach should be taken to resolving mental health crises through providing the support services that police require. Supporting police involves maintaining confidence in the institution by providing for increased accountability and independent investigations.

In the 1990s Australia adopted a program of deinstitutionalisation of PMI. The rationale for this program was that those suffering had a right to be integrated with, rather than segregated from, their communities. The program was implemented in response to international principles advocating more humane treatment for PMI. ${ }^{1}$ Unfortunately this was not supported by an increase in community programs. A 1993 Australian Human Rights Commission (AHRC) report found services for those being treated in their communities 'disgraceful' ${ }^{2}$ and that there had been 'virtually no retraining of psychiatric staff to work in a non-institutional setting'. ${ }^{3}$ As a result, many PMI did not receive adequate treatment to manage successfully in the community. This was proposed as a primary reason for the high incidence of interactions between police and PMI. The Police Foundation of Australia (PFA) noted 'persons that are released from institutions are often released directly into the path of local law enforcement ${ }^{\prime 4}$ and that this precipitates 'numerous violent physical confrontations between police and mentally ill persons'.

This claim is supported by a 2013 report from the Australian Institute of Criminology (AIC), which revealed that almost 50 per cent of the persons shot by police in Australia in the preceding two decades were suffering from mental health issues at the time of the incident. ${ }^{6}$ But when considering some of the years covered by this report individually, the number is much higher. For example, in 1994, 2001 and 2003, the figures are 67 per cent, 100 per cent and 71 per cent respectively. ${ }^{7}$ The report identifies these figures as conservative estimates, recognising that actual numbers may have been much higher as there were likely a number of victims with mental illness who were yet to be officially diagnosed. ${ }^{8}$ The report noted that the alleged offender was unarmed in 16 of these cases. ${ }^{9}$

1 United Nations General Assembly A/RES/46/119 Principles 3, 7 and 917 December 1991.

2 Australian Human Rights Commission, National Inquiry into the Human Rights of People with Mental Illness Report (1993).

3 ibid.

4 Police Federation of Australia, Submission to Senate Select Committee on Mental Health, 10 May 20052 [3].

ibid., 1 [5].

Australian Institute of Criminology, Police Shootings of People with a Mental Illness (2013) No. 34.

ibid., table 1 .

ibid., 1 [7].

ibid., 2 [4]. 


\section{Case Studies}

Individual case studies provide the opportunity to analyse how these scenarios develop. The facts of each case were collected from evidence tendered to the respective coronial inquiries.

\section{Case Study 1: Tyler Cassidy}

On 11 December 2008, 15-year-old Melburnian Tyler Cassidy experienced a crisis of mental health following a documented history of instability; this included episodes of self-harm, suicidal ideation and eventually institutionalisation. ${ }^{10}$ On the evening of 11 December several witnesses contacted emergency services to report interactions with a young man whose behaviour was 'agitated and distressed', 'unstable' and 'intense'. ${ }^{11}$ Cassidy himself called emergency services twice throughout the evening demanding that police be dispatched. ${ }^{12}$ It is unclear what Cassidy's intentions were when making these requests, but when he was encountered by members of Victoria Police (VP), he was verbally abusive and physically threatening, using knives stolen from a nearby department store. ${ }^{13}$ When police ordered Cassidy to drop the knives, he refused. Oleoresin capsicum (OC) spray was deployed, but proved ineffective. ${ }^{14}$ Cassidy advanced upon police, ignoring warning shots and repeated commands that he relinquish his weapons. ${ }^{15}$ The senior officer, Senior Constable Dods, was trapped and believed that he had no choice but to shoot Cassidy twice in the legs. ${ }^{16}$ This was followed by eight more shots, from a total of three VP members, one of which hit Cassidy in the torso and resulted in his death. ${ }^{17}$ From the police's initial encounter with Cassidy to notification of his death a total of 73 seconds elapsed. ${ }^{18}$

\section{Coronial Comments on Police Response}

Her Honour, Coates J, noted that in their interaction with Cassidy police failed to communicate and coordinate ${ }^{19}$ a planned response and that, had they done so, there was the possibility of a different result. She observed that the communications dispatch did not convey vital information to the officers. She noted that it was a failure by Dods to allow himself to be backed into a corner

10 Coroner's Court of Victoria, Finding into Death with Inquest - Tyler Jordan Cassidy, 23 November 2011 15 [49].

11 ibid., 22 [83] [84] 23 [86] 29 [118] 29.

12 ibid., 8 [4].

13 ibid., 7 [3].

14 ibid., 9 [11] [12].

15 ibid., 9 [13].

16 ibid., 9 [16].

17 ibid., 9 [18].

18 ibid., 10 [19].

19 ibid., 69 [337]. 
and that he should have been more aware of his surroundings, or should have been alerted to them by the other attending officers. It was further noted that police issued commands 'in a best drum major's voice' whilst presuming Cassidy's rationality, ${ }^{20}$ which is contrary to accepted protocols. There was also a failure to gather adequate information about the exact nature of the threat, ${ }^{21}$ assess Cassidy's mental state ${ }^{22}$ and determine the potential for Cassidy to be reasoned with, a potential which was found to have existed. ${ }^{23}$ There was no use of de-escalation techniques, ${ }^{24}$ which is required by protocols. There were also significant issues with the investigation of the incident, including a failure to require police to give recorded evidence (thus affording them different treatment to that of the public $)^{25}$ and a failure to perform drug and alcohol testing within required times (despite the fact that some of the officers had attended their Christmas party the night before and had been observed drinking). ${ }^{26}$ Additionally the investigation by VP disregarded requests from community organisations ${ }^{27}$ and Cassidy's family ${ }^{28}$ that it be undertaken by an independent body, such as the Office of Police Integrity (OPI). Although Her Honour found that police training was inadequate, and that the four attending members had at multiple times departed from the training that had been provided, she found neither factor had substantially contributed to Cassidy's death. ${ }^{29}$ It is the opinion of the author that Her Honour erred in this finding.

\section{Case Study 2: Robert Laudisio Curti}

On 18 March 2012 Brazilian national Robert Laudisio Curti suffered psychotic effects from the drug LSD $^{30}$ and was involved in an incident in which he stole biscuits from a convenience store in Sydney's inner city. ${ }^{31}$ A witness reported the incident, ${ }^{32}$ which was mistakenly reported by police dispatch as an armed robbery. ${ }^{33} \mathrm{He}$ was also wrongly identified as attempting to steal a motor vehicle. ${ }^{34}$ 
Curti was pursued initially by six, ${ }^{35}$ and later $11,{ }^{36}$ members of NSW Police who, during the attempted arrest, deployed OC spray at least three times and tasered Curti at least 13 times. ${ }^{37}$ This, combined with the weight of 'half a tonne' ${ }^{\prime 38}$ of officers restraining Curti (which may have led to 'positional asphyxiation'), was declared as the likely result of his death. Although an exact cause of death could not be ascertained to a medical certainty, ${ }^{39}$ the coroner was satisfied that death would not have occurred in the absence of the activity of at least four of the officers. ${ }^{40}$ The coroner was explicit in recording that although the arrest was lawful it was unlikely that Curti presented any significant threat to the life or health of civilians or police. ${ }^{41}$

\section{Coronial Comments on Police Response}

The coroner found that at least four of the police who attended the scene were reckless, careless, dangerous and excessively forceful. ${ }^{42}$ The members gave no thought to assessing Curti's mental state. ${ }^{43}$ Other comments included an acknowledgement that Curti had committed no serious offence. ${ }^{44}$ The transcript records a separate acknowledgement that the use of 'minimal force' ${ }^{45}$ is implicit in all police operations. Although the term now used in New South Wales is 'reasonable force', ${ }^{46}$ this is still framed in reference to the need to use 'minimal force in the execution of arrests' ${ }^{47}$ The coroner described the use of tasers and OC spray as unjustifiable and a breach of accepted procedure. ${ }^{48}$ Questions were raised about issuing junior members with tasers, the training accompanying that issue and the fact that junior members who had employed their weapons had little or no understanding of the procedures governing the use of those weapons. ${ }^{49}$ Also of associated importance is the assertion that the senior member's failure to provide leadership and maintain objectivity was abhorrent. ${ }^{50}$ The evidence given to the hearing by a number of the members was variously described as

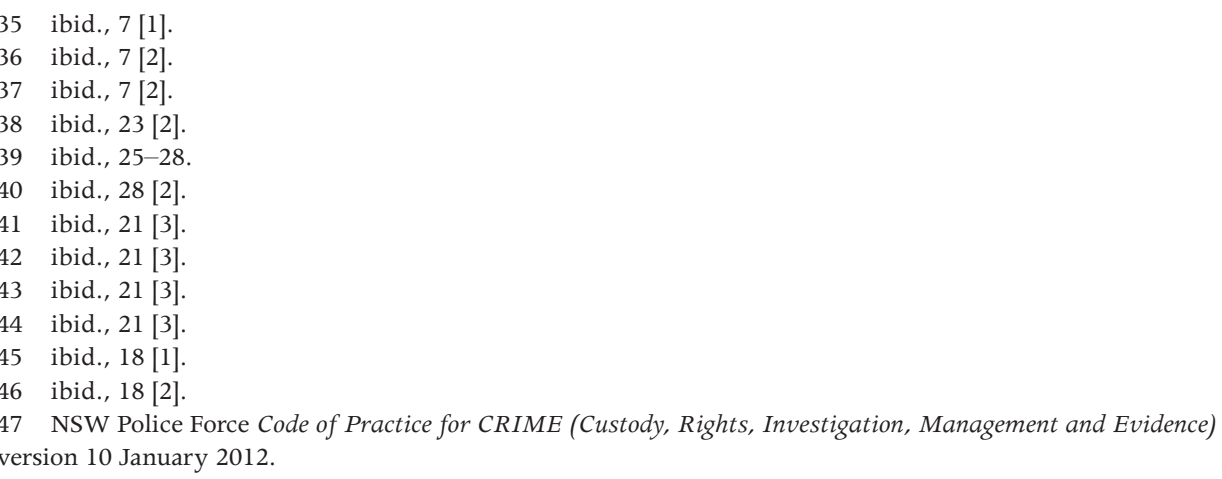


The ANU Undergraduate Research Journal

'contradictory', 51 'self-serving', 52 and 'bearing no credibility'. ${ }^{53}$ The coroner recommended that 'there be a review of communication procedures to ensure that signs of mental disturbance in any person the subject of a police report be communicated, and officers trained further to respond accordingly. ${ }^{\prime 54}$

\section{Case Study 3: Adam Salter}

Adam Salter, a 36-year-old resident of Lewisham in Sydney had suffered a nonviolent history of mental illness, leading to brief period of hospitalisation. ${ }^{55}$ On 18 November 2009 police and paramedics attended his home after Salter's father contacted emergency services to report that Salter was engaging in selfharming behaviour by stabbing himself with a kitchen knife. ${ }^{56}$ Paramedics subdued Salter and began treating his wounds, ${ }^{57}$ which were later reported to be superficial..$^{58}$ Salter's father was taken from the room by police, ${ }^{59}$ at which point Salter freed himself from the restraint of the ambulance staff, regained the knife, (which had been removed from his person, but not the vicinity), and caused himself further harm by stabbing himself in the neck. ${ }^{60}$ The paramedics then called for police assistance, at which point Sergeant Bissett, the senior member in attendance, entered the room, yelled the words 'taser, taser, taser' and shot Salter in the back with her Glock firearm, causing his death. ${ }^{61}$

\section{Coronial Comments on Police Response}

The coroner accepted the evidence tendered by paramedic staff that Salter posed no threat to anyone but himself. ${ }^{62}$ His Honour observed direct contradictions between the evidence provided by police and that provided by the paramedics, Salter's father and the physical evidence. His Honour found that Bissett either made a tragic mistake by intending to discharge the taser but firing her handgun, or that she did intend to discharge her firearm, merely misspoke and 'gave herself very little opportunity to assess the situation and decide whether lethal force really was necessary.' ${ }^{\prime 3}$ It was Bissett's assertion that in fact no mistake was made. She had never intended to draw the taser

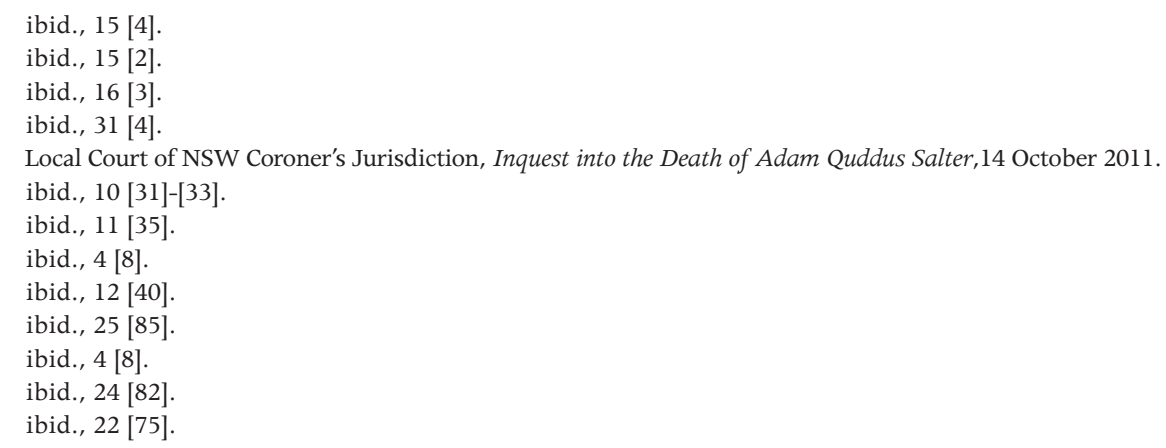


because she had assumed it would not work. ${ }^{64}$ The coroner found that given the circumstances 'it is difficult to see that she (Bissett) gave the use of a less deadly alternative any real consideration. ${ }^{65}$ Although another officer claimed she had issued a warning, no witness (including Bissett) provided a corollary to this and, thus, the coroner rejected that assertion. ${ }^{66}$ It was asserted that Bissett 'fired without much opportunity to assess what was going on and what should happen next'. His Honour found that the attending members had both provided 'false and misleading ${ }^{\prime 67}$ evidence and were 'almost entirely wrong ${ }^{68}$ in their description of events. The situation report was described as 'nonsense' 69 and the walkthrough was considered a 'failure and a disgrace'.$^{70}$ The findings of the coroner speak for themselves:

At best, the police intervention was an utter failure. Police killed the person they were supposed to be helping. They forgot to remove or secure the knife from the sink. They removed from the kitchen the very person, his father, most likely to be able to contain him. They left Adam Salter in the care of a young and inexperienced and, on the evidence of Adrian Salter and the paramedics, ineffective and unresponsive officer. ${ }^{71}$

\section{Commonalities within Case Studies}

The examples detailed above are united by three major elements:

1) Police were ill-prepared to make rational and informed assessments about the situation they faced when confronted with PMI. In each of the above scenarios the inquiries noted that the police response was inadequate in that it was not the result of rational decision-making, but rather was marked by the absence of it. In the Cassidy case, the police team neglected to employ de-escalation as a technique. Further, a better assessment of the situation may have negated the need for weapons to be drawn and a better assessment of the surroundings may have prevented the need for their deployment. In the Curti case there was a clear failure to assess the true risk posed by the suspect and make an informed decision about the degree of force required. In the Salter case the coroner noted that failing to secure the offender's weapon, failing to recognise the value of keeping Salter's father in the room and firing without any real warning were all

64 ibid., 16 [54].

65 ibid., 24 [79].

66 ibid., 18 [61].

67 ibid., 26 [89].

68 ibid., 27 [91].

69 ibid., 27 [91].

70 ibid., 33 [111].

71 ibid., 38 [128]. 
failures to rationally act, rather than react. Perhaps the only means of combatting the ubiquity of this factor is, as the coroner has recommended in each case, increased training and education of officers being sent into the field.

2) Police employed force without regard to proportionality, its necessity nor its probable likely result. In each of the cases it is also clear that weapons were employed disproportionately. Curti posed no risk to the public or officers; Salter posed no risk to any other person than himself, and the coroner rejected claims that he did. Cassidy presented a risk to the officers, however, it is difficult not to take seriously the coroner's finding that perhaps even the drawing of weapons escalated the situation, after which it was difficult to resolve without an increase in aggression from both parties. What is clear from a reading of all the coroners' reports is that necessity and proportionality in reference to the use of force was material to the death of each of the civilians.

3) The investigations, and therefore standards of accountability, were unsatisfactory in examining, assessing and regulating conduct in relation to PMI. As was noted above, there were several issues relating to the investigation of the Cassidy incident. Firstly, that the VP Homicide Squad, instead of an independent body, conducted the investigation is cause for concern. Secondly, it was noted that officers had, during the course of the investigation, covertly recorded interviews with the Cassidy family and, on this, the coroner noted that it was difficult not to draw conclusions about favourable treatment being extended to officers of VP. In the case of the Salter shooting, there was a concerted attempt by the officers involved to create a false impression of the incident in order to deflect responsibility, of which the coroner was scathing. One might further ask questions as to whether this would ever have been revealed had it not been for the presence of independent witnesses from the team of paramedics. One could further ask this question in relation to the Curti case regarding the presence of closed-circuit television footage. There is a demonstrable need for independent investigations of such incidents whenever a question arises as to the propriety of police conduct. It is not enough that independent bodies may undertake such investigations; in order to promote public confidence in the institution of policing, such bodies must undertake these investigations.

\section{Recent Developments in Police Operations}

As noted, Australia's policy of deinstitutionalisation in the 1990s led to what was described as 'an inordinately high number of police shootings'. This was most pronounced in Victoria (as continues to be the case), evidenced by figures 
from 1990-97 which indicate that 17 of 32 fatal shootings involved PMI. ${ }^{72}$ It is, therefore, useful to begin a discussion of developments in police operations with the Victorian experience.

\section{Victoria, OSTT and Project Beacon}

In Victoria, police are empowered to apprehend PMI under section 10 of the Mental Health Act (1986). At present a person is detained under section 10 approximately every two hours and an incident involving the use of force occurs approximately every two and a half hours. ${ }^{73}$ In 1994 VP developed Project Beacon as part of the Operational Safety and Tactics Training (OSTT), which operational members are required to attend twice yearly to update academy training. ${ }^{74}$ Underpinning this program are the Project Beacon principles, which include ensuring:

Safety of officers, civilians, offenders and suspects is paramount.

Risk assessment is to be applied to all situations.

Violent confrontations are to be avoided wherever possible.

Use of force is to be avoided.

Minimum force is to be applied where confrontations cannot be avoided.

The safety first principle may require more resources to be be deployed, more complex planning and more time to complete. ${ }^{75}$

The project and its accompanying principles were initially found to be effective in reducing both the use of force and the associated fatalities. When first implemented, Project Beacon was defined as an 'innovative and nation leading project' that 'changed police practices in Victoria'. ${ }^{76}$ It was established in subsequent reviews, however, that there had been a shift away from the focus on reducing force and safety first. In a number of reports the OPI noted that VP demonstrated a 'troubling cyclical pattern' ${ }^{\prime 7}$ in that it seemed to implement change as a result of public controversy and, with the fading of that controversy, returned to former practices. The OPI warned VP that it was not managing the risks associated with the use of force and charged that 'it lacked the will or capacity to implement solutions to effectively address the identified problems' ${ }^{78}$ What is clear is that Project Beacon was working;

72 Office of Police Integrity, Policing People Who Appear to be Mentally Ill (2012) 17 [5].

73 Office of Police Integrity, Review of the Use of Force by and against Victorian Police (2009) 8.

74 Above $n 1060$ [292].

75 Above n 1061 [295] (Victoria Police Manual — Policy Rules - Operational safety and equipment).

76 Office of Police Integrity, Review of the Use of Force by and Against Victorian Police (2009) 9.

77 ibid., n 6932 [3].

78 ibid., 14. 
confrontations were being more effectively and safely managed. Had this shift away from the Project Beacon principles not occurred, the Cassidy incident may have produced a different result.

The OPI made several recommendations to VP in relation to its preparedness to manage interactions with PMI. One suggestion was that it consider adopting a model based on the NSW Mental Health Intervention Team (MHIT), which it claims is the closest approximation in Australia to the successful Memphis Model, discussed below. ${ }^{79}$ One of the benefits of the Memphis Model is that it creates partnerships with mental health and emergency services. As the OPI observed in its review 'all too often police cannot obtain the services or responses necessary to assist the individual' and, importantly, 'police cannot achieve better outcomes for this vulnerable section of our community by themselves. This requires a renewed commitment to a whole-of-government response to mental health. ${ }^{\prime 80}$

Unfortunately, despite recommendations, VP declined to implement such a program.

\section{The Memphis Model, New South Wales and the MHIT}

The Memphis Model began in Tennessee in 1988, and was developed to respond to challenges presented by deinstitutionalisation in that jurisdiction. ${ }^{81}$ The Memphis Police Department joined in partnership with the Memphis Chapter of the National Alliance on Mental Illness (NAMI), mental health providers, and two local universities (the University of Memphis and the University of Tennessee) in organising, training, and implementing a specialised unit. ${ }^{82}$ In 2008, after the introduction of the Mental Health Act (2007) (which provides for police apprehensions under section 22), New South Wales adapted and introduced this program for its own use. ${ }^{83}$ The NSW MHIT includes officers with specialist training and a clinical nurse. It has resulted in the development of stronger relationships with mental health services, an increase in the use of de-escalation techniques and an increase in the confidence of MHIT-accredited officers when dealing with PMI. ${ }^{84}$ The program was reviewed by the Charles Sturt University (CSU) Graduate School of Policing and Centre for Inland Health and was noted to

\footnotetext{
79 ibid., n 6941 [6].

80 ibid., n 6942 [2].

81 Robert Vaughan, Crisis Intervention Team 'The Memphis Model' (2011) Official Site of the Memphis Police Department http://www.memphispolice.org/crisis\%20intervention.htm.

82 ibid., 2.

83 NSW Police Newsletter Mental Health Intervention Team January 2008. police.nsw.gov.au/_data/assets/ pdf_file/0014/123314/newsletter_200801.pdf.

84 Victoria Herrington, Katrina Clifford, Pota F Lawrence, Sharon Ryle, and Rod Pope Impact of the NSW Police Force Mental Health Intervention Team: Final Evaluation Report Charles Sturt University.

85 Centre for Inland Health Australian Graduate School of Policing December 2009 2-5.
} 
have led to a marked improvement in police/PMI interactions. ${ }^{85}$ A major limitation, however, remains with the program's implementation. Current figures indicate $300^{86}$ operational NSW police officers have undertaken MHIT training. In a force that numbers somewhere between 15,400 and $16,200,{ }^{87}$ the vast majority of NSW police are not receiving the benefit of this training. Aspirational targets of 10 per cent implementation by 2015 are insufficient. ${ }^{88}$ The CSU review also noted that there remain issues in relation to communicating information regarding PMI to officers in the field and recommended training for radio dispatchers. ${ }^{89}$ These issues are particularly important in the context of the Salter and Curti shootings. Better trained officers with a better understanding of best practice in relation to PMI and a more concerted attempt to reduce the confusion with dispatch communication may have altered the development of those incidents. Another problem lies in formulating effective inter-agency agreements. NSW Police has an inter-agency memorandum of understanding (MOU) with NSW Health and the Ambulance Service, which it updated in 2007..$^{90}$ The CSU review was concerned that the MOU had not been further updated to reflect the legislative changes in 2007. This was preventing police from achieving its inter-agency objectives of further reducing police involvement in PMI related incidents. ${ }^{91}$

\section{Accountability}

A number of recent changes have occurred in accountability in relation to this issue in both New South Wales and Victoria.

\section{Victoria}

In 2012 the OPI was replaced by the Independent Broad-based Anti-Corruption Commission (IBAC). ${ }^{92}$ This was hailed as an improvement in accountability and the related Act empowers IBAC to investigate either on the basis of a complaint or its own motion. ${ }^{93}$ It is worth recording here that the OPI also possessed these powers ${ }^{94}$ and determined not to use them in the Cassidy investigation. Legislative amendments are of value only to the extent that they are applied. The application of IBAC's powers will need to be closely monitored to ensure effectiveness.

\footnotetext{
86 ibid.

86 NSW Police Force Mental Health Corporate Spokesperson Message (Media Release February 2013) http:// www.police.nsw.gov.au/community_issues/mental_health.

87 NSW Police Force Operational Capacity 3 May.

88 See above $\mathrm{n} 83$.

89 See above $\mathrm{n} 815$ recommendation $1(\mathrm{~b})$.

90 Memorandum of Understanding for Mental Health Emergency Response — July 2007.

91 See above $\mathrm{n} 812$ recommendation 3.

92 Independent Broad-based Anti-corruption Commission Act 2011 (Vic).

93 Independent Broad-based Anti-corruption Commission Act 2011 (Vic) s 64(1)(c).

94 Office of Police Integrity Act 2008 (Vic).
} 
NSW

On 28 May $2013^{95}$ and 26 June $2013^{96}$ the Police Integrity Commissioner (PIC) referred officers involved in the Salter and Curti incidents to the Director of Public Prosecutions for criminal charges. Although this is a welcome sign that police in NSW are being held to higher standards of accountability, it also revealed the flawed nature of the investigative process. It is concerning that the officers involved in the Salter matter were initially recommended for a bravery award. ${ }^{97}$ Vigilance is required on the part of the NSW Critical Incident Investigators to ensure public confidence is maintained at all levels. This is particularly true in matters involving vulnerable members of the community.

\section{Conclusion}

This essay has outlined some issues associated with policing the mentally ill. Based on the above research it is recommended that improvements in New South Wales be built upon and delivered to all operational officers. It is further recommended that VP consider implementing a program reflecting the Memphis Model. A whole-of-government approach is required to address the complexities of policing PMI, and greater communication and cooperation between agencies is a necessary element of this. Greater emphasis must also be placed upon training and oversight of the use of force. It is unacceptable that 44 per cent of victims of police shootings are PMI; that 16 of those victims were unarmed makes it more urgent to prioritise these imperatives. Whilst there have been some welcome changes to the accountability regimes in both New South Wales and Victoria, more must be done to ensure confidence in the institution of policing and the performance of its functions.

\section{Bibliography}

\section{Articles/Books/Reports}

Australian Human Rights Commission, National Inquiry into the Human Rights of People with Mental Illness Report (1993).

Australian Institute of Criminology, Police Shootings of People with a Mental Illness 34 (2013).

95 New South Wales Police Integrity Commission: Operation Anafi (Media Release May 2013).

96 New South Wales Police Integrity Commission: Operation Calyx (Report to Parliament June 2013).

97 ibid. 
Coroner's Court of New South Wales, Inquiry into the Death of Robert Laudisio Curti (2012).

Coroner's Court of Victoria, Finding into Death with Inquest - Tyler Jordan Cassidy (2011).

Coroner's Jurisdiction Local Court of NSW, Inquest into the Death of Adam Quddus Salter (2011).

Herrington, V, Clifford, K, Lawrence, PF, Ryle, S and Pope, R, Impact of the NSW Police Force Mental Health Intervention Team: Final Evaluation Report (Charles Sturt University, 2009).

Office of Police Integrity, Review of the Use of Force by and against Victorian Police (2009).

_ Policing People Who Appear to be Mentally Ill (2012).

\section{Legislation}

Independent Broad-based Anti-corruption Commission Act 2011 (Vic)

Mental Health Act 1986 (Vic)

Mental Health Act 2007 (NSW)

Office of Police Integrity Act 2008 (Vic)

\section{Other}

Ambulance Service of NSW, NSW Health, and NSW Police, Memorandum of Understanding for Mental Health Emergency Response, July 2007, accessed at: http://www.police.nsw.gov.au/_data/assets/pdf_file/0009/98469/mou_mental_ health_emergency_response_nsw_health_ambulance_police200707.pdf.

Shani Cassidy, Letter submitted by Human Rights Law Centre Copy to United Nations Human Rights Committee, May 2013.

Centre for Inland Health Australian Graduate School of Policing, The Impact of the NSW Police Force Mental Health Intervention Team: Final Evaluation Report, December 2009.

Federation of Community Legal Centres, Independent Investigation into the Victoria Police Fatal Shooting of Tyler Cassidy, Letter to the Director of the OPI, 12 May 2009.

NSW Police Newsletter, 'Mental Health Intervention Team', January 2008. 
The ANU Undergraduate Research Journal

NSW Police Mental Health, Corporate Spokesperson Message, February 2013.

NSW Police, Operational Capacity, May 2013.

NSW Police Integrity Commission, Operation Anaf, Media Release, May 2013.

— Operation Calyx, Report to Parliament, June 2013.

Police Federation of Australia, Submission to Senate Select Committee on Mental Health, May 2005.

United Nations General Assembly, The Protection of Persons with Mental Illness and the Improvement of Mental Health Care, /RES/46/119 Principles, 17 December 1991.

Vaughan, R, Crisis Intervention Team 'The Memphis Model' (Official Site of the Memphis Police Department, 2011, accessed at: http://www.memphispolice. org/Crisis\%20Intervention.htm). 
This text taken from The ANU Undergraduate Research Journal Volume Five 2013, published 2014 by ANU Press, The Australian National University, Canberra, Australia. 